\title{
Anti-survival and pro-apoptotic effects of meridianin C derivatives on MV4-11 human acute myeloid leukemia cells
}

\author{
HYORIM CHO ${ }^{1,2^{*}}$, ANIL KUMAR YADAV ${ }^{1 *}$, YOUNGROK DO ${ }^{3}$, MIHWA HEO $^{3}$, \\ DAVID BISHOP-BAILEY ${ }^{4}$, JINHO LEE ${ }^{5}$ and BYEONG-CHURL JANG ${ }^{1}$
}

\author{
${ }^{1}$ Department of Molecular Medicine, College of Medicine, Keimyung University, Daegu 42601; \\ ${ }^{2}$ Korea Pharmaceutical Test and Research Institute, Seoul 07806; ${ }^{3}$ Department of Hematology and Oncology, \\ College of Medicine, Keimyung University, Daegu 42601, Republic of Korea; ${ }^{4}$ Comparative Biomedical Sciences, \\ Royal Veterinary College, London NW 10TU, United Kingdom; ${ }^{5}$ Department of Chemistry, \\ College of Life Science, Keimyung University, Daegu 42601, Republic of Korea
}

Received April 2, 2019; Accepted October 24, 2019

DOI: 10.3892/ijo.2019.4925

\begin{abstract}
Meridianin $\mathrm{C}$ is a marine natural product with anticancer activity. Several meridianin $\mathrm{C}$ derivatives (compounds 7a-j) were recently synthesized, and their inhibitory effects on pro-viral integration site for Moloney murine leukemia virus (PIM) kinases, as well as their antiproliferative effects on human leukemia cells, were reported. However, the anti-leukemic effects and mechanisms of action of meridianin $\mathrm{C}$ and its derivatives remain largely unknown. The aim of the present study was to investigate the effects of meridianin C and its derivatives on MV4-11 human acute myeloid leukemia cell growth. The parent compound meridianin $\mathrm{C}$ did not markedly affect the viability and survival of MV4-11 cells. By contrast, MV4-11 cell viability and survival were reduced by meridianin $\mathrm{C}$ derivatives, with compound $7 \mathrm{a}$ achieving the most prominent reduction. Compound 7a notably inhibited the expression and activity of PIM kinases, as evidenced by reduced B-cell lymphoma-2 (Bcl-2)-associated death promoter phosphorylation at Ser112. However, meridianin C also suppressed PIM kinase expression and activity, and the pan-PIM kinase inhibitor AZD1208 only slightly suppressed the survival of MV4-11 cells. Thus, the anti-survival effect of compound 7a on MV4-11 cells was unrelated to PIM kinase inhibition.
\end{abstract}

Correspondence to: Professor Byeong-Churl Jang, Department of Molecular Medicine, College of Medicine, Keimyung University, 1095 Dalgubeoldaero, Dalseogu, Daegu 42601, Republic of Korea

E-mail: jangbc123@gw.kmu.ac.kr

Professor Jinho Lee, Department of Chemistry, College of Life Science, Keimyung University, 1095 Dalgubeoldaero, Dalseogu, Daegu 42601, Republic of Korea

E-mail: jinho@gw.kmu.ac.kr

${ }^{*}$ Contributed equally

Key words: meridianin $\mathrm{C}$ derivative, caspases, apoptosis, myeloid cell leukemia-1, X-linked inhibitor of apoptosis, MV4-11
Moreover, compound 7a induced apoptosis, caspase-9 and -3 activation and poly(ADP-ribose) polymerase (PARP) cleavage, but did not affect death receptor (DR)-4 or DR-5 expression in MV4-11 cells. Compound 7a also induced the generation of cleaved Bcl-2, and the downregulation of myeloid cell leukemia (Mcl)-1 and X-linked inhibitor of apoptosis (XIAP) in MV4-11 cells. Furthermore, compound 7a increased eukaryotic initiation factor (eIF)-2 $\alpha$ phosphorylation and decreased S6 phosphorylation, whereas GRP-78 expression was unaffected. Importantly, treatment with a pan-caspase inhibitor (z-VAD-fmk) significantly attenuated compound 7a-induced apoptosis, caspase- 9 and -3 activation, PARP cleavage, generation of cleaved Bcl-2 and downregulation of Mcl-1 and XIAP in MV4-11 cells. Collectively, these findings demonstrated the strong anti-survival and pro-apoptotic effects of compound $7 \mathrm{a}$ on MV4-11 cells through regulation of caspase-9 and -3, Bcl-2, Mcl-1, XIAP, eIF-2 $\alpha$ and S6 molecules.

\section{Introduction}

Acute myeloid leukemia (AML) is a malignant hematopoietic stem cell disorder with markedly heterogeneous cytogenetic and genomic alterations (1,2). In 2018, 60,300 new AML cases were reported in the United States (3). Despite the development and clinical application of novel targeted chemotherapeutic agents, improved radiation techniques, hematopoietic stem cell transplantation and other treatment protocols, the overall survival rates have increased only minimally over the last two decades (4). Therefore, more effective and non-toxic therapeutics are urgently needed in leukemia treatment.

Several therapeutic and chemopreventive drugs eliminate cancerous cells by inducing apoptosis. Cancer cells undergoing apoptosis display a number of characteristics, such as plasma membrane blebbing, cell shrinkage, mitochondrial depolarization, chromatin condensation and DNA fragmentation $(5,6)$. Caspases are vital for the execution of apoptosis triggered by apoptotic stimuli (7). Caspase activities are regulated by the expression of B-cell lymphoma-2 (Bcl-2) and inhibitor of apoptosis protein (IAP) families $(8,9)$ Mounting evidence has demonstrated the modulation of Bcl-2 
and IAP expression by anticancer agents in several leukemia cells (10-13). The pro-virus integration site for Moloney murine leukemia virus (PIM) kinases, including PIM-1, -2 and -3 , are active serine/threonine kinases with overlapping functions and substrate specificities (14). Previous studies demonstrated the overexpression of PIM kinases in a number of hematological malignancies and solid tumors (15-19). Moreover, growth suppression and/or apoptosis induction due to silencing and/or pharmacological inhibition of PIM kinases were reported in several blood and solid cancer cells (20-22). These results strongly support the oncogenic role of PIM kinases.

Meridianin $\mathrm{C}$ is one of the natural indole alkaloids (meridianin A-G) isolated from the marine sponge Aplidium meridianum $(23,24)$. The inhibitory and/or antiproliferative effects of meridianin $\mathrm{C}, \mathrm{D}$ or $\mathrm{G}$ analogues/derivatives on hematological and solid cancer cells were previously investigated (25-27). Meridianin C and several meridianin C derivatives (compounds $7 \mathrm{a}-\mathrm{j}$ ) were previously synthesized, and their PIM kinase inhibitory and antiproliferative activities in human leukemia cells were reported (27). In addition, the strong anti-survival, but not pro-apoptotic, effects of meridianin C on YD-10B human tongue cancer cells through macropinocytosis and downregulation of Dickkopf-related protein-3 (DKK-3) were recently reported (28). However, the anti-leukemic effects and underlying mechanisms of action of meridianin $\mathrm{C}$ and its derivatives remain largely unknown. The aim of the present study was to investigate these anti-leukemic effects and mechanisms of action of meridianin $\mathrm{C}$ and its derivatives using MV4-11 human AML cells.

\section{Materials and methods}

Chemicals and antibodies. Meridianin $\mathrm{C}$ and its derivatives (compounds $7 \mathrm{a}-\mathrm{j}$ ) were synthesized as previously described (27) and prepared as $10 \mathrm{mM}$ stock solutions in DMSO. AZD1208 (cat. no. S7104) was purchased from Selleck Chemicals. RPMI-1640 (cat. no. LM011-01), fetal bovine serum (FBS; S001-01), and penicillin/streptomycin cocktail (cat. no. LS202-02) were purchased from Welgene, Inc. Anti-procaspase-9 antibody (cat. no. ADI-AAM-139) was purchased from Enzo Life Sciences, Inc. Anti-death receptor (DR)-5 antibody (cat. no. NBP1-45951) was purchased from Novus Biologicals. Anti-poly(ADP-ribose) polymerase (PARP) antibody (cat. no. 11835238001) was purchased from Roche Diagnostics; anti- $\beta$-actin antibody (cat. no. A5441) was obtained from Sigma-Aldrich; Merck KGaA; anti-human X-linked inhibitor of apoptosis protein (XIAP) antibody (cat. no. AF221) was purchased from R\&D Systems, Inc. Anti-phosphorylated (p)-eukaryotic initiation factor (eIF)- $2 \alpha$ (S51) antibody (cat. no. ab32157) was purchased from Abcam. Anti-p-S6 (S235/236; cat. no. 2211), anti-S6 (cat. no. 2317), anti-eIF-2 $\alpha$ (cat. no. 9722), anti-p-extracellular signal-regulated kinase (ERK)-1/2 (T202/Y204; cat. no. 9101), and anti-ERK-1/2 (cat. no. 9102) antibodies were purchased from Cell Signaling Technology, Inc. Anti-DR-4 (cat. no. sc-8411), anti-PIM-1 (cat. no. sc-13513), anti-PIM-2 (cat. no. sc-271844), anti-PIM-3 (cat. no. sc-293237), anti-p-Bcl-2-associated death promoter (BAD) (Ser112) (cat. no. sc-7998), anti-BAD (cat. no. sc-8044), anti-glucose-regulated protein (GRP)-78 (cat. no. sc-13968), anti-Bcl-2 (cat. no. sc-509), anti-myeloid cell leukemia (Mcl)-1 (cat. no. sc-819), secondary goat anti-rabbit (cat. no. sc-2004), and goat anti-mouse IgG (cat. no. sc-2005) antibodies were purchased from Santa Cruz Biotechnology, Inc. z-VAD-fmk (627610) and protease inhibitor cocktail (PIC, 100X) (539134) were purchased from EMD Millipore. Super Signal $^{\mathrm{TM}}$ West Pico PLUS Enhanced chemiluminescence (ECL; cat. no. 34080) was purchased from Thermo Fisher Scientific, Inc. Well plates (6- and 24-wells) were obtained from SPL Life Sciences.

Cell culture. MV4-11 human AML cells [CRL-9591 ${ }^{\mathrm{TM}}$, American Type Culture Collection (ATCC)] and K562 human chronic myeloid leukemia (CML) cells (CCL-243 ${ }^{\mathrm{TM}}$, ATCC) were grown in RPMI-1640 supplemented with $10 \%$ heat-inactivated FBS and $1 \%$ penicillin/streptomycin at $37^{\circ} \mathrm{C}$ in humidified air (95\% air and 5\% $\mathrm{CO}_{2}$ ). MV4-11 and $\mathrm{K} 562$ cells carried a Fms-like tyrosine kinase 3 internal tandem duplication and a breakpoint cluster region-Abelson mutation, respectively $(29,30)$.

Cell count analysis. MV4-11 or K562 cells were treated with vehicle control (DMSO; 0.1\%), meridianin C, meridianin C derivatives and/or AZD1208 at indicated concentrations (1, 5 and $10 \mu \mathrm{M}$ ) for different durations (24 and $48 \mathrm{~h}$ ). The number of surviving cells was counted with the trypan blue exclusion method, which based on the principle that live cells have intact cell membranes and cannot be stained. Briefly, equal amounts $(15 \mu \mathrm{l})$ of $0.4 \%$ trypan blue dye (cat. no. 15250-061, Gibco; Thermo Fisher Scientific, Inc.) were added to the cell suspension and mixed by pipetting up and down. The mixture was incubated for $1 \mathrm{~min}$ at room temperature $\left(25-27^{\circ} \mathrm{C}\right)$, after which time $10 \mu \mathrm{l}$ of the mixture was added to the hemocytometer and cells were counted under a phase-contrast microscope. Approximately 50 cells were counted in each evaluation.

Cell viability assay. MV4-11 cells were treated with vehicle control (DMSO; 0.1\%), meridianin C, meridianin C derivatives and/or AZD1208 at indicated concentrations (1, 5 and $10 \mu \mathrm{M})$ for different durations ( 24 and $48 \mathrm{~h}$ ). At the end of treatment, $20 \mu \mathrm{l}$ of MTS solution was added to each well, and the plates were incubated at $37^{\circ} \mathrm{C}$ for $1 \mathrm{~h}$. The absorbance of each well was measured at $490 \mathrm{~nm}$ using a microplate reader (SPECTRA max 340PC; Molecular Devices, LLC).

Measurement of DNA fragmentation. Measurement of DNA fragmentation was conducted as previously described (21). Briefly, MV4-11 cells were seeded into 6-well plates at a density of $2 \times 10^{5}$ cells $/ \mathrm{ml}$ with a volume of $2 \mathrm{ml}$ in each well on the day prior to treatment. Cells were treated with vehicle control (DMSO) or compound $7 \mathrm{a}(1,5$ and $10 \mu \mathrm{M})$ and/or z-VAD-fmk $(50 \mu \mathrm{M})$ at the indicated concentrations for 24 and 48 h. MV4-11 cells were then harvested, washed and lysed in a lysis buffer [50 mM Tris (pH 8.0), 0.5\% sarkosyl, $0.5 \mathrm{mg} / \mathrm{ml}$ proteinase $\mathrm{K}$ and $1 \mathrm{mM}$ EDTA] at $55^{\circ} \mathrm{C}$ for $3 \mathrm{~h}$. Subsequently, RNase A $(0.5 \mu \mathrm{g} / \mathrm{ml})$ was added and the lysate was further incubated at $55^{\circ} \mathrm{C}$ for $18 \mathrm{~h}$. Finally, the lysate was centrifuged at $10,000 \mathrm{x} \mathrm{g}$ at $4^{\circ} \mathrm{C}$ for $20 \mathrm{~min}$. Genomic DNA was extracted and analyzed via electrophoresis at $100 \mathrm{~V}$ on a $1.8 \%$ agarose gel for $20 \mathrm{~min}$. The DNA was visualized and photographed under UV illumination after staining with ethidium bromide 
$(0.1 \mu \mathrm{g} / \mathrm{ml}$; Sigma-Aldrich; Merck KGaA) using a gel documentation system (Gel Doc-XR; Bio-Rad Laboratories, Inc.).

Preparation of whole-cell lysates. MV4-11 cells were grown in 6-well plates at a density of $0.25 \times 10^{6}$ cells $/ \mathrm{ml}$ on the day prior to treatment. After treatment and at each time point, the cells were washed twice with PBS, and proteins were extracted using modified RIPA buffer [50 mM Tris- $\mathrm{Cl}$ ( $\mathrm{pH} 7.4), 150 \mathrm{mM}$ $\mathrm{NaCl}, 0.1 \%$ sodium dodecyl sulfate, $0.25 \%$ sodium deoxycholate, $1 \%$ Triton X-100, $1 \%$ Nonidet P-40, 1 mM EDTA, $1 \mathrm{mM}$ EGTA and PIC (1X)]. Cell lysates were collected and centrifuged at $12,074 \mathrm{xg}$ for $20 \mathrm{~min}$ at $4^{\circ} \mathrm{C}$. Protein concentration in the supernatant was determined by using a bicinchoninic acid protein assay kit (Thermo Fisher Scientific, Inc.).

Western blotting. Western blotting was performed as previously described $(10,21)$. Briefly, equal amounts of protein $(50 \mu \mathrm{g})$ were separated via 10\% SDS-PAGE and transferred onto polyvinylidene fluoride membranes (EMD Millipore) by electroplating. The membranes were washed with Tris-buffered saline (TBS; $10 \mathrm{mM}$ Tris, $150 \mathrm{mM} \mathrm{NaCl}, \mathrm{pH}$ 7.5) supplemented with $0.05 \%(\mathrm{v} / \mathrm{v})$ Tween-20 (TBS-T), followed by blocking with TBS-T containing 5\% (w/v) non-fat dried milk. The membranes were probed overnight using antibodies against PIM-1 (1:2,000), PIM-2 (1:2,000), PIM-3 (1:2,000), p-BAD $(1: 2,000)$, T-BAD $(1: 2,000)$, procaspase-9 $(1: 2,000)$, procaspase-3 (1:2,000), DR-4 (1:2000), DR-5 (1:2,000), PARP (1:2,000), XIAP (1:1,000), Bcl-2 (1:1,000), Mcl-1 (1:1,000), p-eIF-2 $\alpha(1: 2,000)$, T-eIF-2 $\alpha(1: 2,000)$, GRP-78 $(1: 1,000)$, p-S6 (1:3,000), S6 (1:3,000), p-ERK-1/2 (1:2,000), T-ERK-1/2 $(1: 2,000)$ or $\beta$-actin $(1: 10,000)$ at $4^{\circ} \mathrm{C}$, followed by incubation with secondary antibodies conjugated to horseradish peroxidase at room temperature for $2 \mathrm{~h}$. The membranes were washed, and immune reactivities were detected by Super Signal ${ }^{\mathrm{TM}}$ West Pico PLUS ECL (Thermo Fisher Scientific, Inc.) according to the manufacturer's instructions. Equal protein loading was assessed via $\beta$-actin expression levels.

Reverse-transcription polymerase chain reaction (RT-PCR) analysis. Total cellular RNA from conditioned MV4-11 cells was isolated using TRIzol ${ }^{\circledR}$ reagent (Thermo Fisher Scientific, Inc.) according to the manufacturer's protocol. RT-PCR was performed as previously described $(10,21)$. Briefly, equal amounts of total RNA $(5 \mu \mathrm{g})$ were reverse-transcribed in a $40-\mu 1$ reaction mixture containing $8 \mu 1$ Molony Murine Leukemia Virus Reverse Transcriptase (M-MLV RT) 5X buffer, $3 \mu 110 \mathrm{mM}$ dNTPs, $0.45 \mu \mathrm{l} 40 \mathrm{U} / \mu 1 \mathrm{RNase}$ inhibitor, $0.3 \mu \mathrm{l} 200 \mathrm{U} / \mu \mathrm{l}$ M-MLV RT (Promega Corporation) and $3.75 \mu \mathrm{l}$ $20 \mu \mathrm{M}$ oligo dT (Bioneer Corporation). Single-stranded cDNA was amplified by PCR using $4 \mu \mathrm{l} 5 \mathrm{X}$ Green Go-Taq ${ }^{\circledR}$ Flexi reaction buffer, $0.4 \mu \mathrm{M} 10 \mathrm{mM}$ dNTPs, $0.1 \mu 15 \mathrm{U} / \mu 1$ Taq polymerase, $1.2 \mu 125 \mathrm{mM} \mathrm{MgCl} 2$ (Promega Corporation), and $0.4 \mu 1$ primer $(20 \mathrm{pM} / \mu \mathrm{l})$. The following primer pairs were used: DR-4 sense, 5'-CTGAGCAACGCAGACTCGCTGTCC AC-3' and antisense, 5'-AAGGACACGGCAGAGCCTGTGCC AT-3'; DR-5 sense, 5'-AGCCGCTCATGAGGAAGTTGG-3' and antisense, 5'-GGCAAGTCTCTCTCCCAGCGTCTC-3' Mcl-1 sense, 5'-ATCTCTCGGTACCT TCGGGAG-3' and antisense, 5'-ACCAGCTCCTACTCCAGCAAC-3'; Bcl-2 sense, 5'-GTGGAGGAGCTCTTCAGGGA-3' and antisense,
5'-AGGCACCCAGGGTGATGCAA-3'; XIAP sense, 5'-CGT CGATTTTGTGCTCGTCAG-3' and antisense, 5'-GAAGCA TTTATCAGGGTTATTGTCTCATG-3'; and actin sense, 5'-TCAAGATCATTGCTCCTCCTG-3' and antisense, 5'-CTG CTTGCTGATCCACATCTG-3'. The PCR conditions were as follows: For DR-4 and DR-5: 35 cycles of denaturation at $95^{\circ} \mathrm{C}$ for $30 \mathrm{sec}$, annealing at $63^{\circ} \mathrm{C}$ for $30 \mathrm{sec}$ and extension at $72^{\circ} \mathrm{C}$ for $30 \mathrm{sec}$; for Mcl-1: 25 cycles of denaturation at $95^{\circ} \mathrm{C}$ for $45 \mathrm{sec}$, annealing at $56^{\circ} \mathrm{C}$ for $45 \mathrm{sec}$ and extension at $72^{\circ} \mathrm{C}$ for $45 \mathrm{sec}$; for Bcl-2: 30 cycles of denaturation at $95^{\circ} \mathrm{C}$ for $45 \mathrm{sec}$, annealing at $56^{\circ} \mathrm{C}$ for $45 \mathrm{sec}$ and extension at $72^{\circ} \mathrm{C}$ for $45 \mathrm{sec}$; for XIAP: 30 cycles of denaturation at $95^{\circ} \mathrm{C}$ for $35 \mathrm{sec}$, annealing at $54^{\circ} \mathrm{C}$ for $40 \mathrm{sec}$ and extension at $72^{\circ} \mathrm{C}$ for $30 \mathrm{sec}$; and for $\beta$-actin: 25 cycles of denaturation at $95^{\circ} \mathrm{C}$ for $30 \mathrm{sec}$, annealing at $56^{\circ} \mathrm{C}$ for $30 \mathrm{sec}$ and extension at $72^{\circ} \mathrm{C}$ for $30 \mathrm{sec}$. $\beta$-actin was used as an internal control to evaluate the relative expressions of DR-4, DR-5, Mcl-1, Bcl-2 and XIAP.

Statistical analyses. Cell count analysis and MTS assay were performed in triplicate and repeated three times. All other data were obtained via at least three independent measurements. Data are expressed as mean \pm standard error of the mean. One-way ANOVA followed by Dunnett's post hoc test was performed using SPSS 11.5 software (SPSS, Inc). P<0.05 was considered to indicate statistically significant differences.

\section{Results}

Compound 7 a strongly reduces the survival and viability of MV4-11 cells, and inhibits PIM kinase activity. We first examined the effects of meridianin $\mathrm{C}$ and its derivatives (compounds 7a-j) at a concentration of $10 \mu \mathrm{M}$ for 24 and $48 \mathrm{~h}$ on the survival and viability of MV4-11 cells. The parent compound meridianin $\mathrm{C}$ did not markedly affect cell growth. By contrast, some of its derivatives, such as compounds $7 \mathrm{a}, 7 \mathrm{~g}$ and $7 \mathrm{j}$, strongly reduced MV4-11 survival and viability after treatment for 24 and $48 \mathrm{~h}$ (Fig. 1A and B). We next investigated the effects of compounds $7 \mathrm{a}, 7 \mathrm{~g}$ and $7 \mathrm{j}$ on MV4-11 cell survival and viability at different concentrations $(1,5$ and $10 \mu \mathrm{M})$ and treatment durations ( 24 or $48 \mathrm{~h}$ ) (Fig. 1C and D). The highest reduction in MV4-11 cell survival and viability was achieved by compound $7 \mathrm{a}$ in a concentration-dependent manner. The effects of compounds $7 \mathrm{~g}$ and $7 \mathrm{j}$ were substantial as well. Compared with the other compounds, meridianin $\mathrm{C}$ exerted no or a very weak inhibitory effect on MV4-11 survival and viability within the tested concentration and for the specified treatment durations. Taking into consideration the PIM kinase inhibitory activities of meridianin C derivatives (27), we next investigated whether MV4-11 cells expressed PIM kinases and whether compound 7a affected PIM kinase expression and activity. PIM kinase activity was assessed by measuring the levels of phosphorylated BAD (Ser112), a downstream target of PIM kinases (31). High and low levels of PIM-3 and PIM-1/PIM-2, respectively, were detected in control MV4-11 cells (Fig. 1E). BAD phosphorylation was also observed. Treatment with compound $7 \mathrm{a}$ for 24 and $48 \mathrm{~h}$ inhibited PIM kinase activity in MV4-11 cells, as evidenced by reduced PIM kinase expression and decreased BAD phosphorylation levels. Densitometry data (PIM-3/actin or p-BAD/T-BAD ratio) were obtained by analyzing Fig. 1E using ImageJ software 


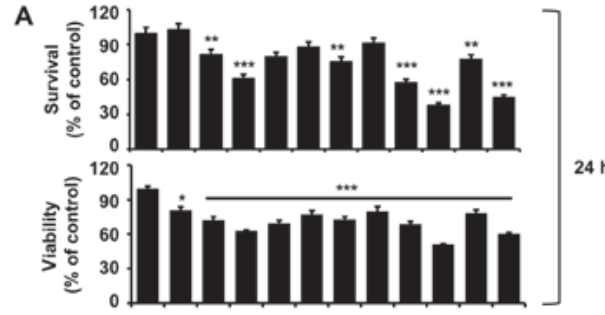

B

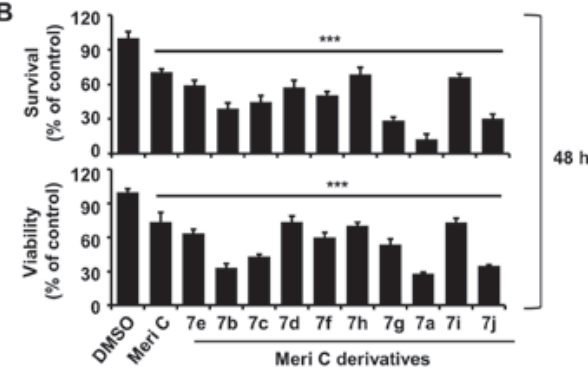

E

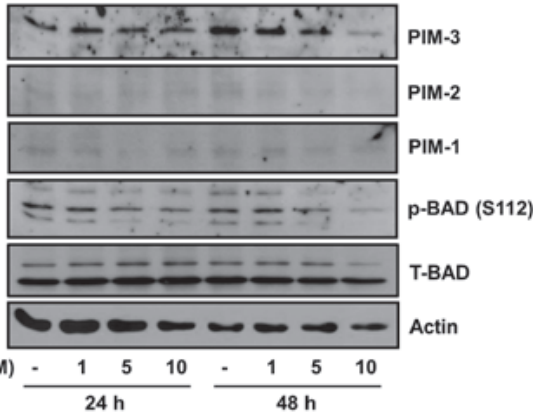

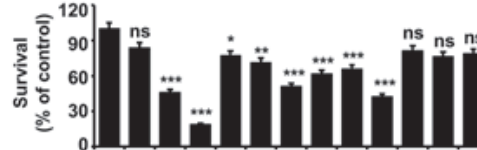

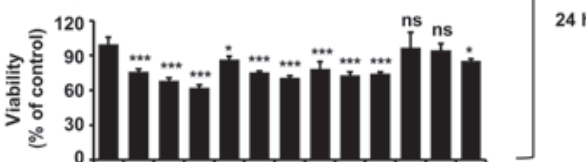

D

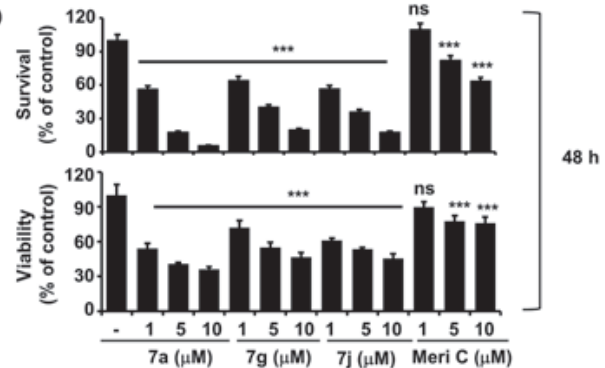

G

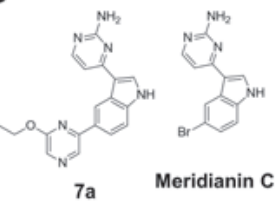

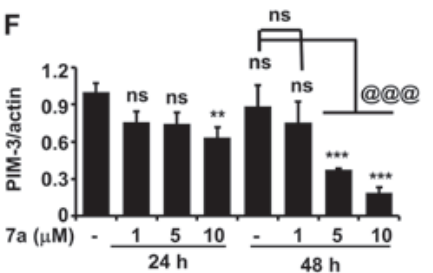

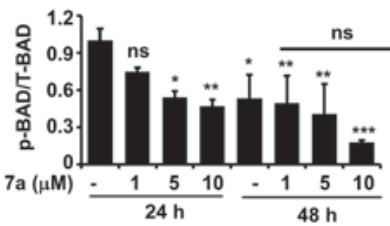

Figure 1. Effects of meridianin C and its derivatives on the growth and/or the expression and activity of PIM kinases in MV4-11 cells. (A and B) MV4-11 cells were treated with vehicle control (DMSO; $0.1 \%$ ), meridianin $\mathrm{C}$ and meridianin $\mathrm{C}$ derivative (compounds $7 \mathrm{a}-\mathrm{j}$ ) at a final concentration of $10 \mu \mathrm{M}$ for 24 and $48 \mathrm{~h}$. The survival percentage or viable cells was measured by cell counting or by using the MTS assay. Experiments were performed in triplicate. Data are the means \pm standard error of the mean of three independent experiments. ${ }^{*} \mathrm{P}<0.05,{ }^{* *} \mathrm{P}<0.01,{ }^{* * *} \mathrm{P}<0.001$ compared with the value of vehicle control at the indicated times. (C and D) MV4-11 cells were treated with vehicle control and compounds $7 \mathrm{a}, 7 \mathrm{~g}$ or $7 \mathrm{j}$ at the indicated concentrations for 24 and $48 \mathrm{~h}$. The survival percentage or viable cells were measured by cell counting or by using the MTS assay. Experiments were performed in triplicate. Data are the means \pm standard error of the mean of three independent experiments. ${ }^{*} \mathrm{P}<0.05,{ }^{* * *} \mathrm{P}<0.01,{ }^{* * * *} \mathrm{P}<0.001$ compared with the value of vehicle control at the indicated times. $(\mathrm{E})$ MV4-11 cells were treated with vehicle control or compound 7a at the indicated concentrations for 24 and $48 \mathrm{~h}$. Whole-cell lysates were prepared and analyzed by western blotting. Each image is representative of three independent experiments. (F) Densitometry data of $(\mathrm{E})$. $^{* *} \mathrm{P}<0.05,{ }^{* *} \mathrm{P}<0.01,{ }^{* * *} \mathrm{P}<0.001 \mathrm{compared}$ with

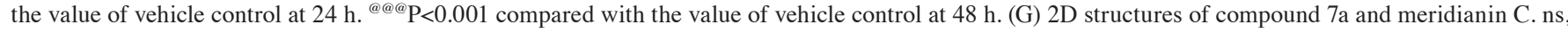
non-significant; Meri C, meridianin C; p-BAD, phosphorylated BAD; T-BAD, total BAD; PIM, pro-viral integration site for Moloney murine leukemia virus kinase; BAD, Bcl-2-associated death promoter.

(version 1.8.0; National Institutes of Health) (Fig. 1F). The $2 \mathrm{D}$ structures of meridianin $\mathrm{C}$ and compound $7 \mathrm{a}$ are shown in Fig. 1G. Due to the stronger inhibitory effect of compound 7a on MV4-11 cell growth, we only focused on this particular meridianin $\mathrm{C}$ derivative in the following analyses.

Compound $7 a$ induces nuclear DNA fragmentation, caspase-9 and -3 activation and PARP cleavage in MV4-11 cells. Whether treatment with compound 7a induced apoptosis in MV4-11 cells was next determined by measuring the level of nuclear DNA fragmentation, a hallmark of apoptosis. Treatment with 5 and $10 \mu \mathrm{M}$ compound $7 \mathrm{a}$ for 24 or $48 \mathrm{~h}$ resulted in marked accumulation of nuclear DNA fragments in MV4-11 cells (Fig. 2A). The expression and activation levels of caspases in MV4-11 cells treated with compound 7a were next determined in order to investigate a possible association between compound 7a-induced apoptosis and caspase activation. Treatment with 5 or $10 \mu \mathrm{M}$ compound $7 \mathrm{a}$ increased and decreased the levels of upstream caspase-9 (proteolytically cleaved active caspase form) and downstream effector caspase-3 (inactive caspase proform) in MV4-11 cells, respectively (Fig. 2B). Caspase activation often leads to the proteolytic cleavage of several target proteins, such as PARP. PARP cleavage was observed in MV4-11 cells following treatment with compound $7 \mathrm{a}$ for 24 and $48 \mathrm{~h}$. The densitometry data of Fig. 2B are shown in Fig. 2C-E. Finally, 

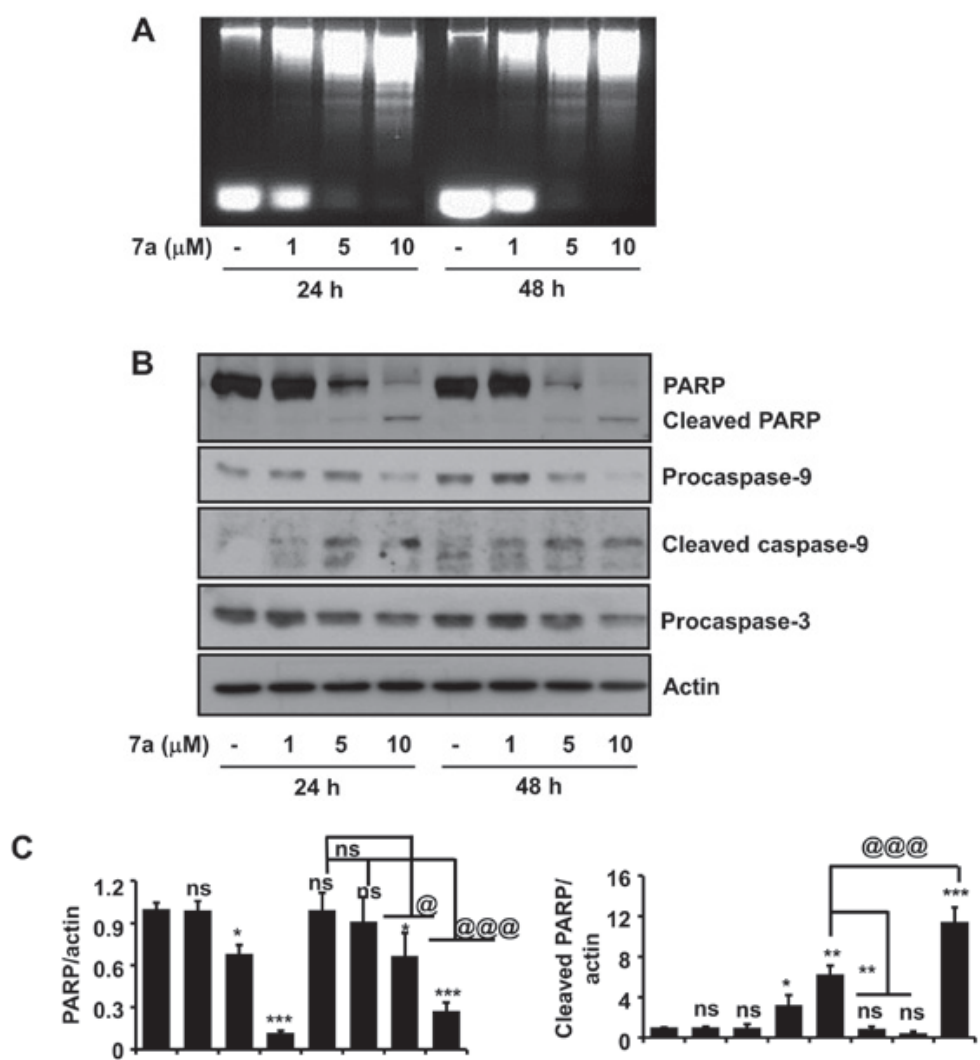

D
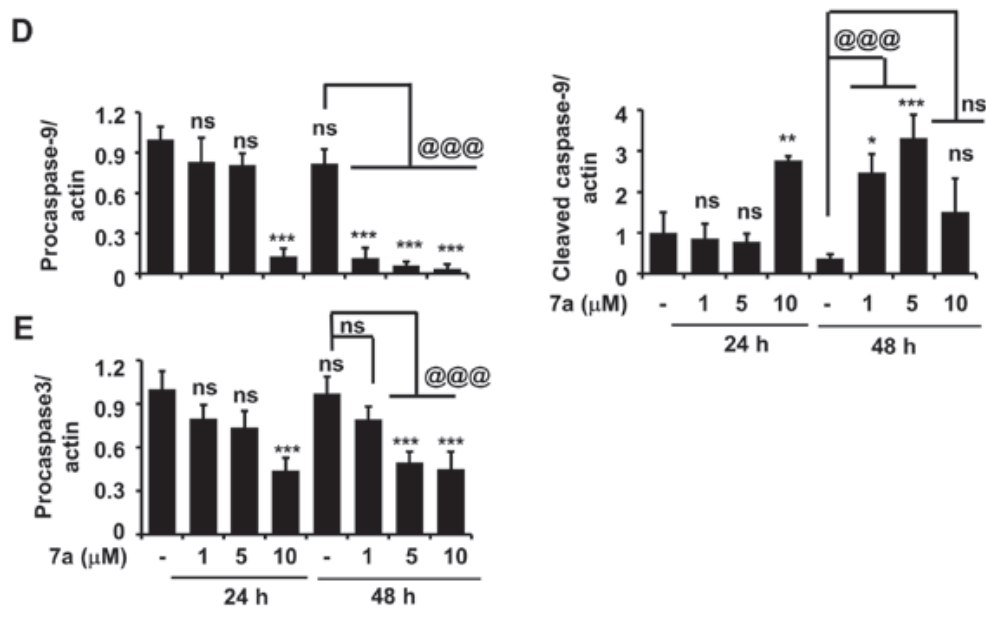

F

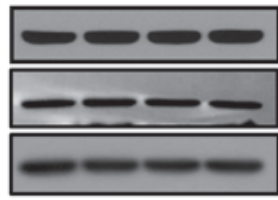

DR-4

DR-5

Actin

G

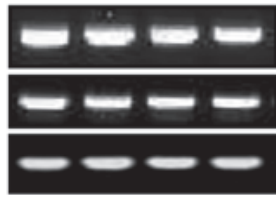

DR-4

DR-5

Actin

7a $(\mu \mathrm{M}) \frac{0}{24} \mathbf{5} \quad 10$

Figure 2. Effects of compound 7a on DNA fragmentation and expression of procaspase-9 and -3, PARP, and DR-4 and-5 in MV4-11 cells. (A) MV4-11 cells were treated with vehicle control (DMSO) or compound $7 \mathrm{a}$ at the indicated concentrations for $24 \mathrm{or} 48 \mathrm{~h}$. At each time point, extranuclear fragmented DNA was extracted and analyzed on a 1.8\% agarose gel. (B) MV4-11 cells were treated with vehicle control (DMSO) or compound 7a at the indicated concentrations for 24 or $48 \mathrm{~h}$. At each time point, whole-cell lysates were prepared and analyzed by western blotting. (C-E) Densitometry analysis of (B). ns, non-significant; ${ }^{*} \mathrm{P}<0.05,{ }^{* *} \mathrm{P}<0.01,{ }^{* * *} \mathrm{P}<0.001$ compared to the value of vehicle control at $24 \mathrm{~h} .{ }^{\circledR} \mathrm{P}<0.01,{ }^{\circledR} @{ }^{\circledR} \mathrm{P}<0.001$ compared to the value of vehicle control at $48 \mathrm{~h}$ (F and G) MV4-11 cells were treated with vehicle control (DMSO) or compound 7a at the indicated concentrations for $24 \mathrm{~h}$. Whole cells lysates and total cellular RNA were prepared and analyzed by western blotting $(\mathrm{F})$ and reverse transcription-polymerase chain reaction analysis, respectively $(\mathrm{G})$. The image is representative of three independent experiments. DR, death receptor. 
A

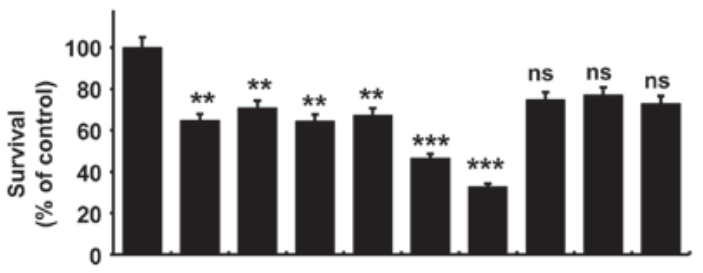

B

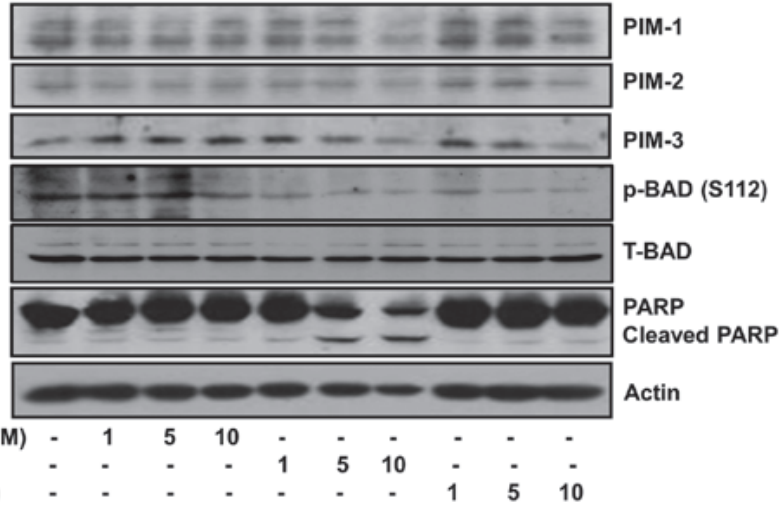

C

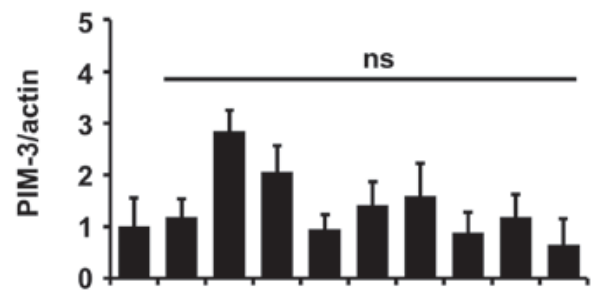

D

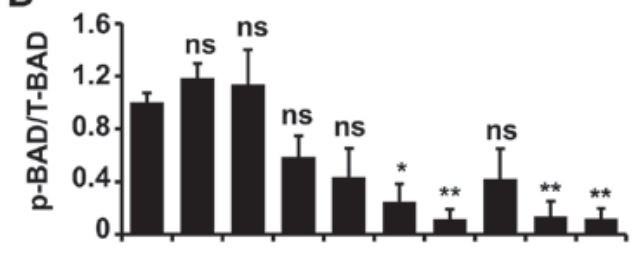

E
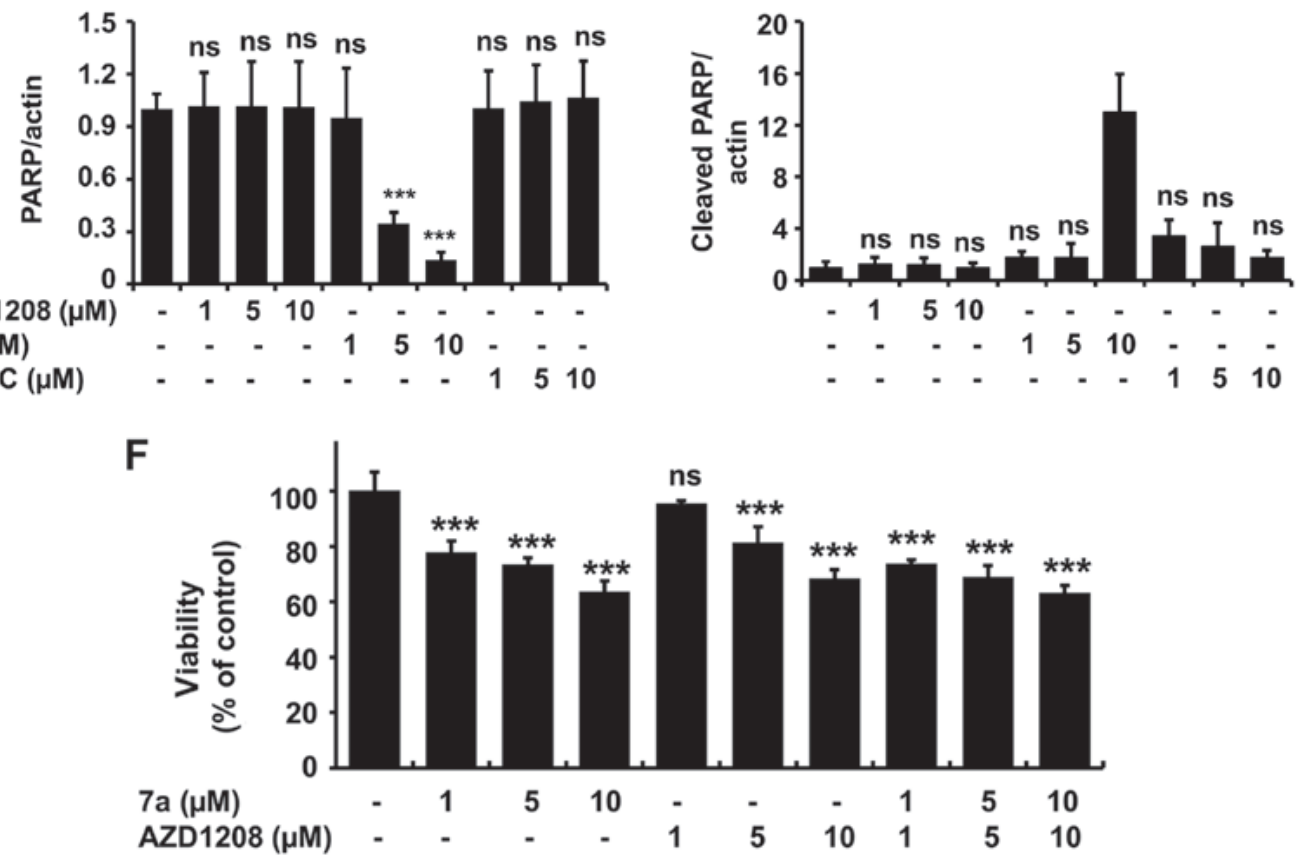

Figure 3. Effects of the pan-PIM inhibitor AZD1208, compound 7a and meridianin C on growth and expression and/or phosphorylation of PIM kinases, BAD and PARP in MV4-11 cells. (A) MV4-11 cells were treated with vehicle control (DMSO; 0.1\%), compound 7a and meridianin C at the indicated concentrations $(1,5$ and $10 \mu \mathrm{M})$ for $24 \mathrm{~h}$. The numbers of surviving cells were measured by using a cell counting assay. The cell counting assay was performed in triplicate. Data are the means \pm standard error of the mean of three independent experiments. ${ }^{* *} \mathrm{P}<0.01,{ }^{* * * *} \mathrm{P}<0.001$ compared to the value of AZD1208, compound $7 \mathrm{a}$ or meridianin C-free control at the indicated times. (B) MV4-11 cells were treated with vehicle control (DMSO; $0.1 \%$ ), compound 7a and meridianin C at the indicated concentrations $(1,5$ and $10 \mu \mathrm{M})$ for $24 \mathrm{~h}$. Whole-cell lysates were prepared and analyzed by western blotting. Each picture is representative of three independent experiments. (C-E) Densitometry data of (B). ${ }^{*} \mathrm{P}<0.05,{ }^{* *} \mathrm{P}<0.01,{ }^{* * *} \mathrm{P}<0.001$ compared to the value of vehicle control at $24 \mathrm{~h}$. (F) MV4-11 cells were treated with vehicle control (DMSO; 0.1\%), compound 7a and/or AZD1208 at the indicated concentrations (1,5 and $10 \mu \mathrm{M})$ for $24 \mathrm{~h}$. The percentage of viable cells was measured using an MTS assay. Experiments were performed in triplicate. Data are the means \pm standard error of the mean of three independent experiments. ${ }^{* * *} \mathrm{P}<0.001$ compared with the value of vehicle control at the indicated times. ns, non-significant; $\mathrm{p}-\mathrm{BAD}$, phosphorylated BAD; T-BAD, total BAD; Meri C; meridianin C; PIM, pro-viral integration site for Moloney murine leukemia virus kinase; BAD, Bcl-2-associated death promoter; PARP, poly(ADP-ribose) polymerase. 
DR-4 and -5 expression levels were measured in MV4-11 cells treated with compound $7 \mathrm{a}$ for $24 \mathrm{~h}$ in order to assess whether compound 7a-induced apoptosis occurred via the extrinsic pathway. The protein and mRNA expression levels of DR-4 and -5 were unaffected in MV4-11 cells treated with 1, 5 and $10 \mu \mathrm{M}$ of compound $7 \mathrm{a}$ (Fig. $2 \mathrm{~F}$ and G). Actin expression levels (control) also remained constant.

Comparison of the effects of compound $7 a$, meridianin $C$ and AZD1208 on MV4-11 cell survival, PIM kinase expression/activity and PARP cleavage.AZD1208 is a highly selective pan-PIM kinase inhibitor (32). We herein evaluated a possible association between the anti-survival and pro-apoptotic effects of compound 7a and PIM kinase inhibition. For this purpose, MV4-11 cells were treated with compound 7a, meridianin C or AZD1208 at different concentrations (1, 5 and $10 \mu \mathrm{M})$, and cell survival, PARP cleavage and PIM kinase expression and activity levels were measured in the conditioned cells. As expected, compound 7a reduced the survival of MV4-11 cells in a concentration-dependent manner (Fig. 3A), and inhibited the expression and activity of PIM kinases (Fig. 3B). There was also slight and marked accumulation of cleaved PARP in MV4-11 cells treated with $5 \mu \mathrm{M}$ and $10 \mu \mathrm{M}$ compound 7a, respectively. However, AZD1208 and meridianin C exerted weaker inhibitory effects on MV4-11 survival compared with compound 7a within the tested concentration range. AZD1208 did not affect the expression of PIM kinases, but weakly inhibited BAD phosphorylation in MV4-11 cells. Moreover, PARP cleavage was not observed in MV4-11 cells treated with AZD1208. Meridianin C exerted little or no effect on PARP cleavage in MV4-11 cells, although it strongly inhibited the expression and activity of PIM kinases. Densitometry data of Fig. 3B are shown in Fig. 3C-E. Actin expression (control) was unchanged. Additionally, the viability of MV4-11 cells treated with combinations of compound 7a and AZD1208 was determined at different concentrations $(1,5$ and $10 \mu \mathrm{M})$ for $24 \mathrm{~h}$, and it was observed that the combination of AZD1208 and compound 7a did not markedly affect the viability of MV4-11 cells (Fig. 3F). These results indicate that AZD1208 does not affect the activity of compound $7 \mathrm{a}$ and the activity of compound 7a is not associated with any effects on PIM kinases.

Compound $7 a$ alters the expression and/or phosphorylation of caspase-9 and -3, PARP, Mcl-1, XIAP, eIF-2 $\alpha$ and S6 in MV4-11 cells. The molecular signaling mechanisms underlying the growth-suppressive and apoptosis-inducing effects of compound 7a were investigated. For this purpose, MV4-11 cells were cultured with or without $5 \mu \mathrm{M}$ compound $7 \mathrm{a}$ for $2,4,8$ or $24 \mathrm{~h}$, and the expression and phosphorylation levels of growth and apoptosis-related factors were measured. Compound 7a treatment led to early activation of caspase-9 and -3 in MV4-11 cells, as evidenced by increased and decreased expression levels of active caspase- 9 and procaspase-3, respectively (Fig. 4A). Compound 7a treatment for $4 \mathrm{~h}$ also led to a marked decrease in PARP protein levels. Moreover, the expressions of Mcl-1 and XIAP proteins were strongly downregulated after $2 \mathrm{~h}$ of treatment with compound 7a in MV4-11 cells, followed by a further decline in levels of these proteins. eIF- $2 \alpha$ phosphorylation increased, whereas S6 phosphorylation decreased
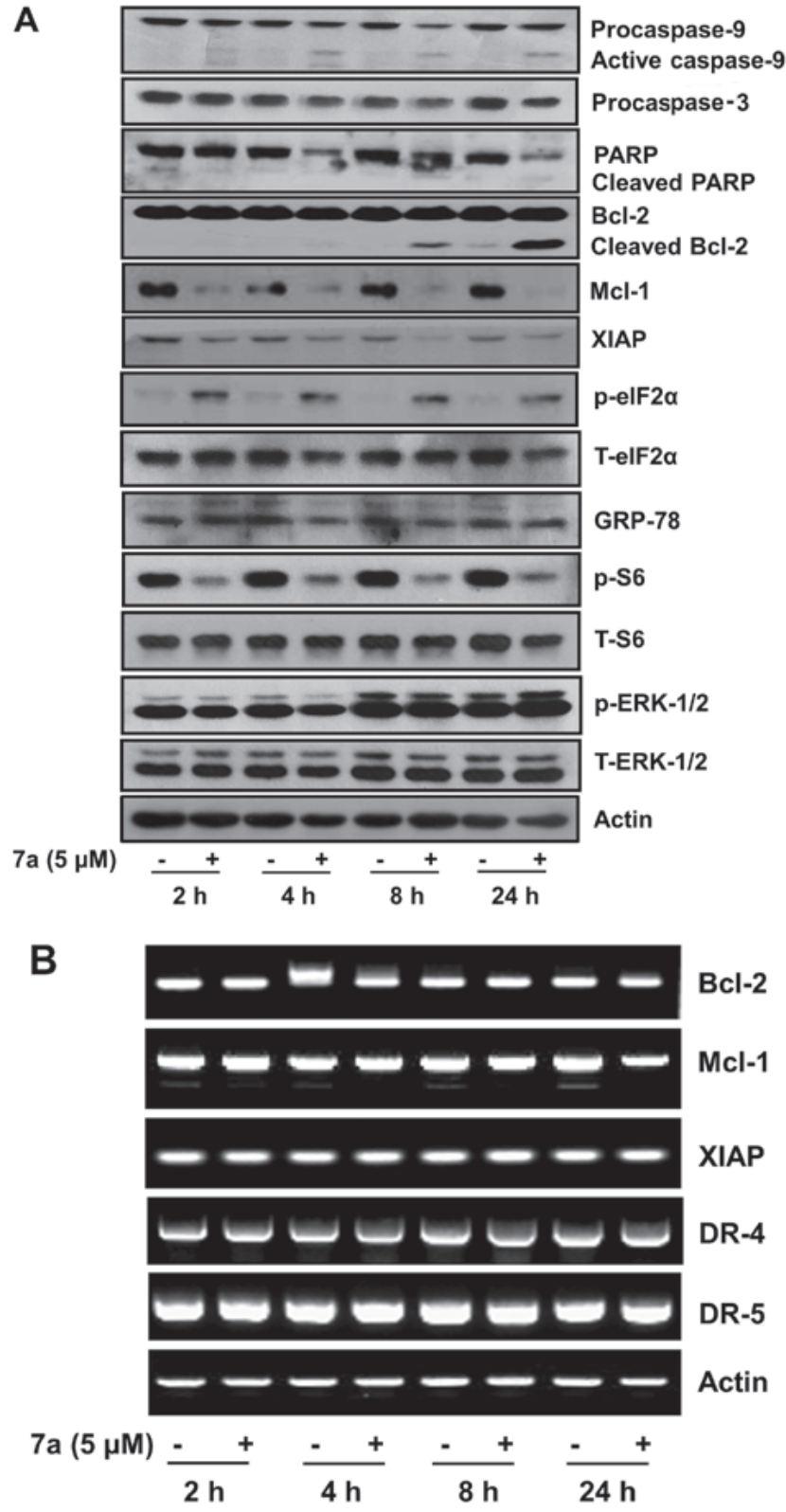

Figure 4. Effects of compound 7a on expression and/or phosphorylation of procaspase-9 and -3, PARP, Bcl-2, Mcl-1, XIAP, eIF-2 $\alpha$, GRP-78, S6, ERK-1/2 and DR-4 and -5 in MV4-11 cells. (A and B) MV4-11 cells were treated with vehicle control (DMSO) or compound $7 \mathrm{a}(5 \mu \mathrm{M})$ for the designated times. (A) At each time point, whole-cell lysates were prepared and analyzed by western blotting. (B) At each time point, total cellular RNA was extracted and analyzed by reverse transcription-polymerase chain reaction analysis. Each picture in (A) or (B) is representative of three independent experiments. p-eIF- $2 \alpha$, phosphorylated eIF-2 $\alpha$; T-eIF-2 $\alpha$, total eIF- $2 \alpha$; p-S6, phosphorylated S6; T-S6, total S6; p-ERK-1/2, phosphorylated ERK-1/2; T-ERK-1/2, total ERK-1/2. PARP, poly(ADP-ribose) polymerase; Bcl-2, B-cell lymphoma 2; Mcl-1, myeloid cell leukemia; XIAP, X-linked inhibitor of apoptosis; eIF, eukaryotic initiation factor; GRP, glucose-regulated protein; ERK, extracellular signal-regulated kinase; DR, death receptor.

in MV4-11 cells after $2 \mathrm{~h}$ of treatment with compound 7a. The expression of GRP-78, an endoplasmic reticulum (ER) stress marker, and the phosphorylation of ERK-1/2, a member of the MAPK family involved in cancer cell growth, remained unchanged in MV4-11 cells upon compound 7a treatment. Total eIF-2 $\alpha$, S6 and ERK-1/2 expression levels remained constant throughout the experiment, except for the significant 
A

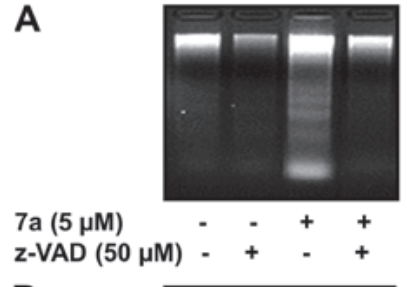

B

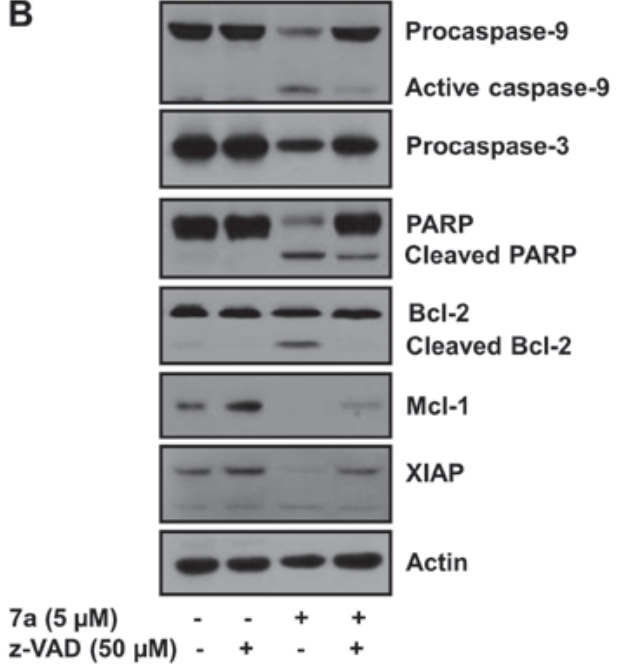

Figure 5. Effects of z-VAD-fmk on compound 7a-induced apoptosis and expression of procaspase-9 and -3, PARP, Bcl-2, Mcl-1 and XIAP in MV4-11 cells. (A and B) MV4-11 cells were pretreated with vehicle control (DMSO) or compound $7 \mathrm{a}(5 \mu \mathrm{M})$ in the absence or presence of the pan-caspase inhibitor z-VAD-fmk $(50 \mu \mathrm{M})$ for $24 \mathrm{~h}$. (A) Extranuclear fragmented DNA was extracted and analyzed on a $1.8 \%$ agarose gel. (B) Whole-cell lysates were analyzed by western blotting. Each picture in (A) or (B) is a representative of three independent experiments. PARP, poly(ADP-ribose) polymerase; Bcl-2, B-cell lymphoma 2; Mcl-1, myeloid cell leukemia; XIAP, X-linked inhibitor of apoptosis.

decrease in the total eIF-2 $\alpha$ and S6 expression levels at $24 \mathrm{~h}$ of compound 7a treatment. Treatment with compound 7a for 2, 4 or $8 \mathrm{~h}$ did not significantly affect Mcl-1 mRNA expression in MV4-11 cells; however, Mcl-1 transcript levels substantially decreased with $24 \mathrm{~h}$ of treatment (Fig. 4B). By contrast, the XIAP, DR-4 and DR-5 mRNA levels remained unchanged in compound 7a-treated MV4-11 cells for all treatment durations. Actin mRNA expression (control) also remained constant.

Pan-caspase inhibitor z-VAD-fmk strongly inhibits compound 7a-induced apoptosis and alteration of PARP, caspase-9 and -3, Bcl-2, Mcl-1 and XIAP expression in MV4-11 cells. The role of caspases in compound 7a-induced apoptosis in MV4-11 cells was next investigated via treatment with the pan-caspase inhibitor z-VAD-fmk. Treatment with $50 \mu \mathrm{M} \mathrm{z}$-VAD-fmk strongly inhibited compound 7a-induced DNA fragmentation (5 $\mu \mathrm{M}$, Fig. 5A), caspase-9 and -3 activation and PARP cleavage (Fig. 5B). Moreover, z-VAD-fmk abolished the ability of compound 7a to induce cleaved Bcl-2 and Mcl-1 and XIAP downregulation. Actin protein expression (control) remained constant.

Compound 7a strongly reduces the survival of K562 human CML cells. Finally, K562 CML cells were treated with compound $7 \mathrm{a}$ or meridianin $\mathrm{C}$ at different concentrations $(1$, 5 and $10 \mu \mathrm{M}$ ) for different durations (24 and $48 \mathrm{~h}$ ), and K562
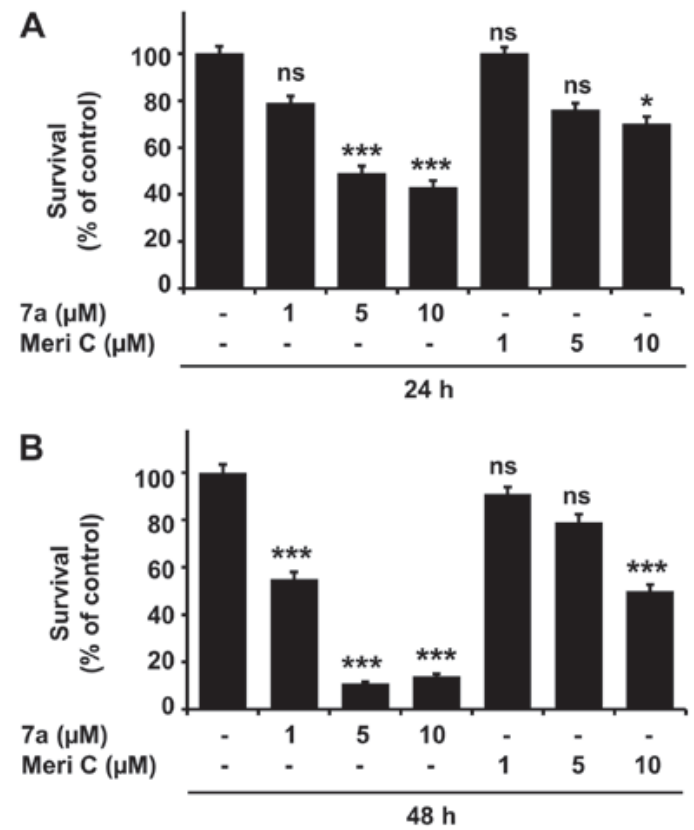

Figure 6. Effects of compound 7a and meridianin C on the growth of K562 human chronic myeloid leukemia cells. (A and B) K562 cells were treated with vehicle control (DMSO; 0.1\%), compound $7 \mathrm{a}$ and meridianin $\mathrm{C}$ at the indicated concentrations $(1,5$ and $10 \mu \mathrm{M})$ for (A) $24 \mathrm{~h}$ and (B) $48 \mathrm{~h}$, respectively. At each time point, the numbers of surviving cells were determined by using a cell counting assay. The cell counting assay was performed in triplicate. Data are the means \pm standard error of the mean of three independent experiments. ${ }^{*} \mathrm{P}<0.05,{ }^{* * *} \mathrm{P}<0.001$ compared with the value of DMSO control at the indicated times. ns, non-significant; Meri C, meridianin C.

cell survival was measured in order to determine whether the growth inhibitory effect of compound 7a is limited to MV4-11 cells. Meridianin $\mathrm{C}$ and compound 7a weakly and strongly reduced the survival of K562 cells, respectively (Fig. 6A and B). In particular, treatment with $5 \mu \mathrm{M}$ compound $7 \mathrm{a}$, rather than meridianin $\mathrm{C}$, for 24 and $48 \mathrm{~h}$ resulted in a markedly higher reduction of K562 survival.

\section{Discussion}

Analogues/derivatives of meridianin C, D or G inhibit the proliferation of hematological and solid tumor cells (25-27). However, the regulation of leukemic cancer cell growth by meridianin $\mathrm{C}$ and its derivatives remains unclear. The present study demonstrated that a meridianin $\mathrm{C}$ derivative, compound $7 \mathrm{a}$, exerted strong anti-survival and pro-apoptotic effects on MV4-11 human AML cells by regulating the expression of caspase-9 and -3, Bcl-2, Mcl-1, XIAP, eIF- $2 \alpha$ and S6 molecules.

Mounting evidence has demonstrated the overexpression of PIM kinases and the oncogenic/pro-survival role of this overexpression in a number of hematological malignancies (15-17,20). PIM kinase inhibitors exhibiting promising antitumor activities in different AML cells, xenograft models and AML patients were recently developed $(15-21,32)$. These results strongly support the use of PIM kinases as targets in leukemia treatment. We previously demonstrated the antiproliferative effects of meridianin $\mathrm{C}$ derivatives on human leukemia cells, including MV4-11 cells (27), via an MTT-based cell proliferation assay; however, the underlying 
mechanism remained elusive. In the present study, while the parent compound meridianin $\mathrm{C}$ only weakly affected the survival of MV4-11 cells, compound 7a markedly reduced it. Although other meridianin $\mathrm{C}$ derivatives, such as compounds $7 \mathrm{~g}$ and $7 \mathrm{j}$, also exerted growth inhibitory effects on MV4-11 cells, their effects were notably weaker compared with that of compound 7a, particularly at a concentration of $5 \mu \mathrm{M}$. Meridianin C derivatives, including compound 7a, were previously shown to exert inhibitory effects against different PIM kinases with different potencies in cell-free systems (27). In the present study, compound 7a inhibited the expression and activity of PIM kinases in MV4-11 cells, as evidenced by the reduced PIM kinase expression and decreased BAD Ser112 phosphorylation levels. Meridianin C also suppressed PIM kinase expression and activity, and the pan-PIM kinase inhibitor AZD1208 exerted a weak inhibitory effect on MV4-11 cell survival. Combined treatment with AZD1208 and compound 7a did not significantly affect MV4-11 cell viability. Hence, PIM kinase inhibition is unlikely a key mechanism in the anti-survival effect of compound 7a on MV4-11 cells.

Compound 7a notably induced apoptosis in MV4-11 cells, as evidenced by increased nuclear DNA fragmentation and PARP cleavage. Apoptosis is mainly mediated via intrinsic (mitochondrial) and extrinsic (DR-mediated) pathways (33), where either mitochondria-mediated caspase-9 or DR-dependent caspase- 8 activation, respectively, mediates the events. In the present study, compound 7a induced caspase- 9 and -3 activation without affecting DR-4 or -5 expression in MV4-11 cells, and the pan-caspase inhibitor z-VAD-fmk greatly attenuated compound 7a-induced apoptosis. Hence, the pro-apoptotic effects of compound 7a on MV4-11 cells may be mainly associated with the intrinsic apoptosis pathway.

A hallmark of cancer is apoptosis evasion, which is often associated with the upregulation of anti-apoptotic proteins, such as the Bcl-2 family proteins. The Bcl-2 family of proteins, including $\mathrm{Bcl}-2$ and $\mathrm{Mcl}-1$, regulate apoptosis and caspase activation by controlling the mitochondrial membrane integrity (34). Mcl-1 is a critical survival factor for multiple myeloma cells (35), as deduced from apoptosis induction via downregulation of Mcl-1 by anti-sense RNA, and delay of caspase activation via Mcl-1 overexpression. A role of $\mathrm{Mcl}-1$ in the survival of AML and chronic lymphocytic leukemia cells has also been hypothesized $(13,36)$. Moreover, downregulation of Bcl-2 family proteins has been associated with the apoptotic effects of certain anticancer agents (10-12). Interestingly, compound $7 \mathrm{a}$ treatment in the present study led to the progressive accumulation of cleaved Bcl-2 and the rapid downregulation of Mcl-1 at the protein level in MV4-11 cells. It is worth noting that caspases, particularly caspase-3, mediate the cleavage of anti-apoptotic Bcl-2 $(37,38)$. Proteasome-dependent Mcl-1 protein degradation/downregulation in AML cells upon treatment with anticancer agents was introduced recently (39). AML cells were also reported to express high Mcl-1 levels. shRNA-mediated Mcl-1 depletion induced apoptosis, whereas Mcl-1 overexpression promoted cell survival (40). In the present study, the pan-caspase inhibitor z-VAD-fmk strongly inhibited compound 7a-induced accumulation of cleaved Bcl-2 and Mcl-1 downregulation in MV4-11 cells. Thus, caspase activation is likely responsible for compound 7a-induced Bcl-2 cleavage and Mcl-1 down- regulation. Caspase-dependent $\mathrm{Bcl}-2$ degradation and loss of Mcl-1 may further contribute to the pro-apoptotic and/or anti-survival effects of compound 7a. Human IAPs, including XIAP and HIAP-1/2, are anti-apoptotic proteins (8). In particular, XIAP has been reported to directly inhibit caspase family members, including caspase-3 (41) and caspase-9 (42). We herein demonstrated that compound 7 a reduced XIAP protein expression in MV4-11 cells, and z-VAD-fmk strongly blocked this process. These data suggest that caspase activation was further responsible for the compound 7a-induced XIAP downregulation in MV4-11 cells, and loss of XIAP is likely to favor caspase activation and apoptosis induction in cells treated with compound 7a.

ER stress induction is a common effect of several anticancer agents (43). Cells undergoing ER stress are characterized by the upregulation of molecular chaperones (e.g., GRP-78) and phosphorylation of eIF-2 $\alpha$ along with inhibition of global translation (44). In the present study, compound 7a rapidly induced eIF- $2 \alpha$ phosphorylation, yet did not affect GRP-78 expression in MV4-11 cells, suggesting regulation of translation rather than ER stress induction. S6 is a ribosomal protein involved in protein synthesis (45). S6 hyperphosphorylation is associated with increased growth or survival of cancer cells (46). Compound 7a rapidly and sustainably inhibited S6 phosphorylation in MV4-11 cells. Thus, the anti-survival and/or pro-apoptotic effects of compound 7a on MV4-11 cells are partly due to the eIF- $2 \alpha$ and S6-dependent translation interference. As aforementioned, we recently reported the strong anti-survival, but not pro-apoptotic, effects of meridianin C on YD-10B cells through macropinocytosis and DKK-3 downregulation (independently of the caspase pathway) (28). Our results demonstrated that, while compound 7 a exerts strong anti-survival and pro-apoptotic effects on MV4-11 cells via activation of the caspase pathways, meridianin $\mathrm{C}$ does not exert such effects. The discrepancy between these results from MV4-11 cells and those previously obtained from YD-10B cells may be attributed to the differences between the ability of each compound to induce activation of the caspase pathways, and the use of different cell types (e.g., leukemia vs. solid cancer) with different characteristics (e.g., floating vs. adherent). It is also interesting to note how the structural difference between compound $7 \mathrm{a}$ and the parent compound meridianin $\mathrm{C}$ resulted in differences in biological activity. Unlike meridianin $\mathrm{C}$, a unique structural moiety within the compound 7 a structure may be associated with its strong anti-survival, pro-apoptosis and caspase-activating effects on MV4-11 cells. Compound 7a has an ethoxypyrazine substituent, which is bulkier and more polar compared with the bromo substituent of meridianin $\mathrm{C}$. This structural feature may have contributed to the differences in biological activity observed herein.

The effects of compound $7 \mathrm{a}$ and meridianin $\mathrm{C}$ on the growth of K562 human CML cells were also examined, and compound $7 \mathrm{a}$ was found to exert a significantly stronger growth inhibitory effect on K562 cells compared with meridianin $\mathrm{C}$ (particularly at a concentration of $5 \mu \mathrm{M}$ ). Hence, the anti-survival effects of compound 7 a were not limited to MV4-11 AML cells.

In summary, to the best of our knowledge, the present study is the first to demonstrate the strong anti-survival and pro-apoptotic effects of compound $7 \mathrm{a}$, a meridianin $\mathrm{C}$ derivative, on 
MV4-11 AML cells. These effects were mediated via control of the expression and phosphorylation of caspase-9 and -3 , Mcl-1, Bcl-2, XIAP, eIF-2 $\alpha$ and S6 molecules. Although important issues remain to be further elucidated, such as the antitumor effects of compound $7 \mathrm{a}$ on animal models, these findings suggest that compound 7a may serve as a basis for the development of novel anti-leukemic agents.

\section{Acknowledgements}

Not applicable.

\section{Funding}

The present study was supported and funded by a National Research Foundation of Korea (NRF) grant from the Korean Government (MSIP) (no. 2014R1A5A2010008).

\section{Availability of data and materials}

All the data generated or analysed during the present study are included in this published article.

\section{Authors' contributions}

HRC and AKY performed the experiments. YRD, MHH and DBB analyzed the data. JL and BCJ designed and supervised the study. AKY, DBB and BCJ wrote the paper.

\section{Ethics approval and consent to participate}

Not applicable.

\section{Patient consent to publication}

Not applicable.

\section{Competing interests}

All the authors declare that they have no competing interests.

\section{References}

1. Kornblau SM, Tibes R, Qiu YH, Chen W, Kantarjian HM, Andreeff M, Coombes KR and Mills GB: Functional proteomic profiling of AML predicts response and survival. Blood 113 154-164, 2009

2. Short NJ, Rytting ME and Cortes JE: Acute myeloid leukaemia. Lancet 392: 593-606, 2018.

3. National Cancer Institute: Cancer Stat Facts: Leukemia. https://seer.cancer.gov/statfacts/html/leuks.html. Accessed March 2, 2019

4. Ossenkoppele G and Löwenberg B: How I treat the older patient with acute myeloid leukemia. Blood 125: 767-774, 2015.

5. Wyllie AH, Kerr JF and Currie AR: Cell death: The significance of apoptosis. Int Rev Cytol 68: 251-306, 1980.

6. Chen Q, Kang J and Fu C: The independence of and associations among apoptosis, autophagy, and necrosis. Signal Transduct Target Ther 3: 18, 2018.

7. Cohen GM: Caspases: The executioners of apoptosis. Biochem J 326: 1-16, 1997.

8. Deveraux QL and Reed JC: IAP family proteins--suppressors of apoptosis. Genes Dev 13: 239-252, 1999.

9. Kale J, Osterlund EJ and Andrews DW: BCL-2 family proteins: Changing partners in the dance towards death. Cell Death Differ 25: 65-80, 2018.
10. Jang BC, Paik JH, Jeong HY, Oh HJ, Park JW, Kwon TK, Song DK, Park JG, Kim SP, Bae JH, et al: Leptomycin B-induced apoptosis is mediated through caspase activation and down-regulation of Mcl-1 and XIAP expression, but not through the generation of ROS in U937 leukemia cells. Biochem Pharmacol 68: 263-274, 2004.

11. Rao J, Xu DR, Zheng FM, Long ZJ, Huang SS, Wu X, Zhou WH, Huang RW and Liu Q: Curcumin reduces expression of Bcl-2, leading to apoptosis in daunorubicin-insensitive CD34+ acute myeloid leukemia cell lines and primary sorted CD34+ acute myeloid leukemia cells. J Transl Med 9: 71, 2011.

12. Kitada S, Zapata JM, Andreeff M and Reed JC: Protein kinase inhibitors flavopiridol and 7-hydroxy-staurosporine down-regulate antiapoptosis proteins in B-cell chronic lymphocytic leukemia. Blood 96: 393-397, 2000.

13. Luedtke DA, Niu X, Pan Y, Zhao J, Liu S, Edwards H, Chen K, Lin H, Taub JW and Ge Y: Inhibition of Mcl-1 enhances cell death induced by the Bcl-2-selective inhibitor ABT-199 in acute myeloid leukemia cells. Signal Transduct Target Ther 2: 17012, 2017.

14. Nawijn MC, Alendar A and Berns A: For better or for worse: The role of Pim oncogenes in tumorigenesis. Nat Rev Cancer 11: 23-34, 2011.

15. Decker S, Finter J, Forde AJ, Kissel S, Schwaller J, Mack TS, Kuhn A, Gray N, Follo M, Jumaa H, et al: PIM kinases are essential for chronic lymphocytic leukemia cell survival (PIM2/3) and CXCR4-mediated microenvironmental interactions (PIM1). Mol Cancer Ther 13: 1231-1245, 2014.

16. Lu J, Zavorotinskaya T, Dai Y, Niu XH, Castillo J, Sim J, Yu J, Wang Y, Langowski JL, Holash J, et al: Pim2 is required for maintaining multiple myeloma cell growth through modulating TSC2 phosphorylation. Blood 122: 1610-1620, 2013.

17. Gómez-Abad C, Pisonero H, Blanco-Aparicio C, Roncador G, González-Menchén A, Martinez-Climent JA, Mata E, Rodríguez ME, Muñoz-González G, Sánchez-Beato M, et al: PIM2 inhibition as a rational therapeutic approach in B-cell lymphoma. Blood 118: 5517-5527, 2011.

18. Guo S, Mao X, Chen J, Huang B, Jin C, Xu Z and Qiu S: Overexpression of Pim-1 in bladder cancer. J Exp Clin Cancer Res 29: 161, 2010.

19. Wang J, Anderson PD, Luo W, Gius D, Roh M and Abdulkadir SA: Pim 1 kinase is required to maintain tumorigenicity in MYC-expressing prostate cancer cells. Oncogene 31: 1794-1803, 2012.

20. Keane NA, Reidy M, Natoni A, Raab MS and O'Dwyer M: Targeting the Pim kinases in multiple myeloma. Blood Cancer J 5: e325, 2015.

21. Yadav AK, Kumar V, Bailey DB and Jang BC: AZD1208, a Pan-Pim Kinase Inhibitor, Has Anti-Growth Effect on 93T449 Human Liposarcoma Cells via Control of the Expression and Phosphorylation of Pim-3, mTOR, 4EBP-1, S6, STAT-3 and AMPK. Int J Mol Sci 20: 2, 2019.

22. Cervantes-Gomez F, Chen LS, Orlowski RZ and Gandhi V: Biological effects of the Pim kinase inhibitor, SGI-1776, in multiple myeloma. Clin Lymphoma Myeloma Leuk 13 (Suppl 2): S317-S329, 2013.

23. Gompel M, Leost M, De Kier Joffe EB, Puricelli L, Franco LH, Palermo J and Meijer L: Meridianins, a new family of protein kinase inhibitors isolated from the ascidian Aplidium meridianum. Bioorg Med Chem Lett 14: 1703-1707, 2004.

24. Bharate SB, Yadav RR, Battula S and Vishwakarma RA: Meridianins: Marine-derived potent kinase inhibitors. Mini Rev Med Chem 12: 618-631, 2012.

25. Giraud F, Alves G, Debiton E, Nauton L, Théry V, Durieu E, Ferandin Y, Lozach O, Meijer L, Anizon F, et al: Synthesis, protein kinase inhibitory potencies, and in vitro antiproliferative activities of meridianin derivatives. J Med Chem 54: 4474-4489, 2011.

26. Radwan MA and El-Sherbiny M: Synthesis and antitumor activity of indolylpyrimidines: Marine natural product meridianin D analogues. Bioorg Med Chem 15: 1206-1211, 2007.

27. More KN, Jang HW, Hong VS and Lee J: Pim kinase inhibitory and antiproliferative activity of a novel series of meridianin C derivatives. Bioorg Med Chem Lett 24: 2424-2428, 2014.

28. Park NS, Park YK, Ramalingam M, Yadav AK, Cho HR Hong VS, More KN, Bae JH, Bishop-Bailey D, Kano J, et al: Meridianin C inhibits the growth of YD-10B human tongue cancer cells through macropinocytosis and the down-regulation of Dickkopf-related protein-3. J Cell Mol Med 22: 5833-5846, 2018. 
29. Drexler HG, MacLeod RA and Uphoff CC: Leukemia cell lines: In vitro models for the study of Philadelphia chromosome-positive leukemia. Leuk Res 23: 207-215, 1999.

30. Meshinchi S and Appelbaum FR: Structural and functional alterations of FLT3 in acute myeloid leukemia. Clin Cancer Res 15: 4263-4269, 2009.

31. Macdonald A, Campbell DG, Toth R, McLauchlan H, Hastie CJ and Arthur JS: Pim kinases phosphorylate multiple sites on Bad and promote 14-3-3 binding and dissociation from Bcl-XL. BMC Cell Biol 7: 1, 2006.

32. Keeton EK, McEachern K, Dillman KS, Palakurthi S, Cao Y, Grondine MR, Kaur S, Wang S, Chen Y, Wu A, et al: AZD1208, a potent and selective pan-Pim kinase inhibitor, demonstrates efficacy in preclinical models of acute myeloid leukemia. Blood 123: 905-913, 2014.

33. Galluzzi L, Vitale I, Aaronson SA, Abrams JM, Adam D, Agostinis P, Alnemri ES, Altucci L, Amelio I, Andrews DW, et al: Molecular mechanisms of cell death: Recommendations of the Nomenclature Committee on Cell Death 2018. Cell Death Differ 25: 486-541, 2018.

34. Festjens N, van Gurp M, van Loo G, Saelens X and Vandenabeele P: Bcl-2 family members as sentinels of cellular integrity and role of mitochondrial intermembrane space proteins in apoptotic cell death. Acta Haematol 111: 7-27, 2004.

35. Zhang B, Gojo I and Fenton RG: Myeloid cell factor-1 is a critical survival factor for multiple myeloma. Blood 99: 1885-1893, 2002

36. Bose P and Grant S: Mcl-1 as a Therapeutic Target in Acute Myelogenous Leukemia (AML). Leuk Res Rep 2: 12-14, 2013.

37. Cheng EH, Kirsch DG, Clem RJ, Ravi R, Kastan MB, Bedi A, Ueno K and Hardwick JM: Conversion of Bcl-2 to a Bax-like death effector by caspases. Science 278: 1966-1968, 1997.

38. Kirsch DG, Doseff A, Chau BN, Lim DS, de Souza-Pinto NC, Hansford R, Kastan MB, Lazebnik YA and Hardwick JM: Caspase-3-dependent cleavage of $\mathrm{Bcl}-2$ promotes release of cytochrome c. J Biol Chem 274: 21155-21161, 1999.
39. Kapoor S, Natarajan K, Baldwin PR, Doshi KA, Lapidus RG, Mathias TJ, Scarpa M, Trotta R, Davila E, Kraus M, et al: Concurrent Inhibition of Pim and FLT3 Kinases Enhances Apoptosis of FLT3-ITD Acute Myeloid Leukemia Cells through Increased Mcl-1 Proteasomal Degradation. Clin Cancer Res 24: 234-247, 2018

40. Kasper S, Breitenbuecher F, Heidel F, Hoffarth S, Markova B, Schuler $M$ and Fischer T: Targeting MCL-1 sensitizes FLT3-ITD-positive leukemias to cytotoxic therapies. Blood Cancer J 2: e60, 2012.

41. Deveraux QL, Takahashi R, Salvesen GS and Reed JC: X-linked IAP is a direct inhibitor of cell-death proteases. Nature 388: 300-304, 1997.

42. Shiozaki EN, Chai J, Rigotti DJ, Riedl SJ, Li P, Srinivasula SM, Alnemri ES, Fairman R and Shi Y: Mechanism of XIAP-mediated inhibition of caspase-9. Mol Cell 11: 519-527, 2003.

43. Han M, Gao H, Xie J, Yuan YP, Yuan Q, Gao MQ, Liu KL, Chen XH, Han YT and Han ZW7: Hispidulin induces ER stress-mediated apoptosis in human hepatocellular carcinoma cells in vitro and in vivo by activating AMPK signaling pathway. Acta Pharmacol Sin 40: 666-676, 2019.

44. de Haro C, Méndez R and Santoyo J: The eIF-2alpha kinases and the control of protein synthesis. FASEB J 10: 1378-1387, 1996.

45. Ruvinsky I and Meyuhas O: Ribosomal protein S6 phosphorylation: From protein synthesis to cell size. Trends Biochem Sci 31: 342-348, 2006.

46. Chen B, Tan Z, Gao J, Wu W, Liu L, Jin W, Cao Y, Zhao S, Zhang W, Qiu Z, et al: Hyperphosphorylation of ribosomal protein S6 predicts unfavorable clinical survival in non-small cell lung cancer. J Exp Clin Cancer Res 34: 126, 2015. 